小特集/膜厚測定法

\title{
エリプソメトリーによる膜厚測定
}

河 村 守 康*

\section{Measurement of Film Thickness by Ellipsometry}

\section{Moriyasu KAWAMURA*}

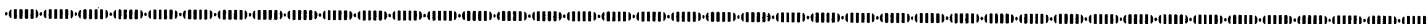

Key Words : Ellipsometry, Film, Refractive Index

エリプソメトリー(偏光反射解析法) による膜 厚測定の理論と装置を紹介する。適用例として, 金属および半導体上の酸化皮膜の測定, ならびに 電析金属皮膜の測定さらに顕微エリプソメトリー の応用例を報告する。

\section{1.はじめに}

偏光した可視光反射を用いて，固体表面の物性， 特に表面に存在する薄膜を解析する手法は, 数多 く存在する。エリプソメトリー（偏光反射解析法） はその 1 つであるが, 定量性が高いこと, ならび に表面の光学特性 (屈折率) が同時に测定できる などの利点がある。しかし，定量性を高く用いる ためには, その計算過程をていねいに行う必要が あり，また計算には複素数を取り扱う必要がある

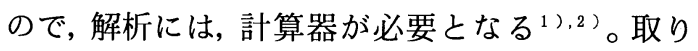
扱うあのが常に一定であり, その屈折率の変化が ない場合には, 前むって理論計算を行っておき， 検量線をチャートしておくなどの手数を踏めば, 簡単で精度の高い膜厚計として利用できる。

\section{2.エリプソメトリーの原理と特徴 ${ }^{3) .4)}$}

偏光が, 気体（あるいは液体）－固体界面で反 射するときには, 強度変化とともに位相変化を受

*(佅溝尻光学工業所 技術部（T141 東京都品川区西 品川2-8-2, 03-492-1905)

Mizojiri Optical Co., Ltd. (8-2, Nishi-Shina gawa 2-chome, Shinagawa-ku, Tokyo 141)

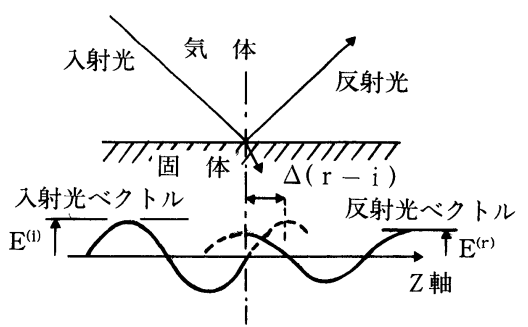

図 1 気体一固体界面での光の反射 反射時に振幅変化 $\left(E^{(1)} \rightarrow E^{(r)}\right)$ とともに位相変化 $(\Delta(\mathrm{r}-1))$ が起こる。

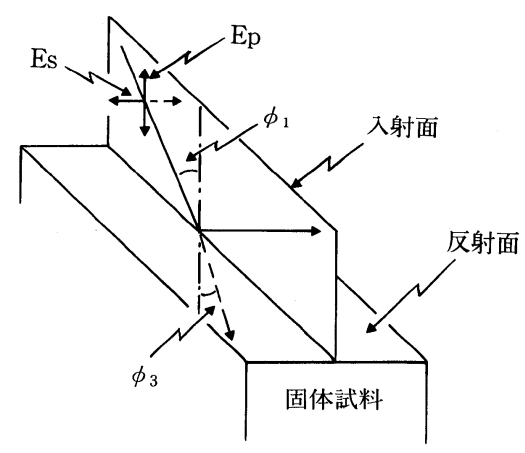

図 2 相界面における斜め入射偏光の入射光之反射光 $\Phi_{1}$ は入射角, $\Phi_{3}$ は複素屈折率。入射面は入射光と反射光を 含め面で定義される。

ける。エリプソメトリーでは, この反射時の強度 変化と位相変化をむとに固体表面の解析を行う。

光の進む方向を $Z$ 軸にすると, 偏光の電場べク トルの複素数表示は次の式となる。

$$
\hat{E}=|E| \exp i(k z-\omega t+\Delta) \cdots \cdots(1)
$$

ここで, $k$ は光 (電磁波) の波数, $\omega$ が角周波数, 
(A)
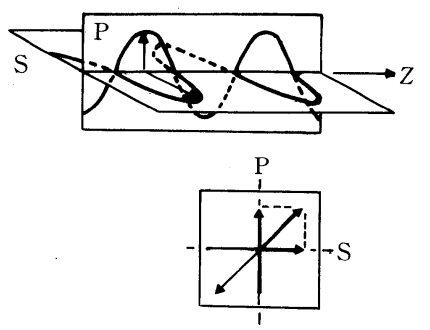

(B)
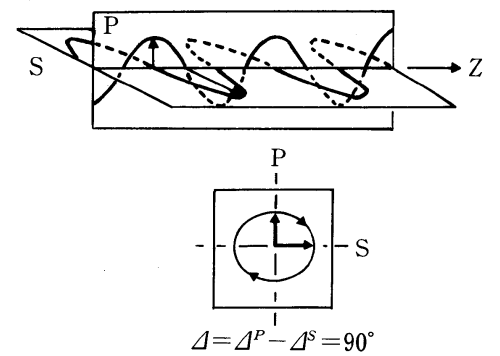

図 32 つの独立した偏光成分のベクトル和で表わさ れる種々の偏光

（A）では $\mathrm{P}$ 偏光成分と $\mathrm{S}$ 偏光成分の位相差がない場合（直線 偏光)。（B）は位相差が $(\pi / 2)$ radianの場合（だ円偏光。 （A）（B）の下の図はZZ軸の方向汃ら偏光を見た場合の電場 ベクトルの動きを示している。

$\Delta$ は位相項, ならびに $|E|$ は強度っまり振幅 である。反射時には，kならびに $\omega$ は一定のままな ので，|E|と $\Delta$ が変化することとなる（図１）。

1 つの波長の偏光の形状を定義するには，2つ の独立した偏光成分のベクトル和で書くことがで きる。図 2 に示すような斜め入射の系を考えると, 2 つの独立成分として, 入射面 (入射光と反射光 を含む面) 内で振動する電場べクトルを持つ偏光 (平行 $(\mathrm{P})$ 成分, $\hat{E}^{\mathrm{P}}$ ) とそれに垂直な電場べク トルを持つ偏光 (垂直 $(\mathrm{S})$ 成分, $\hat{E}^{\mathrm{S}}$ ) を選ぶ ことができる。偏光の形状は, 例えば， $\left|E^{\mathrm{P}}\right|=$ $\left|E^{\mathrm{S}}\right|$ の条件では $\Delta^{\mathrm{P}}-\Delta^{\mathrm{s}}=0$ で, 入射面より $(\pi / 4)$ radian傾いた直線偏光となり, $\Delta^{\mathrm{P}}-\Delta$ $\mathrm{s}=(\pi / 2)$ の場合には, 振幅が一定でその方 向が常に変化している円偏光となる(図 3 )。

反射係数, $\hat{\gamma}$, を入射光と反射光の電場べク卜 ル, $\hat{E}^{(\mathrm{i})}$ と $\hat{E}^{(\mathrm{r})}$ の比と定義すると, P成分な らびに S成分各々について反射係数を書くことが
できる。

$$
\begin{aligned}
& \hat{\gamma}^{\mathrm{P}}=\hat{E}^{\mathrm{P}(\mathrm{r})} / \hat{E}^{\mathrm{P}(\mathrm{i})}=\left|\gamma^{\mathrm{P}}\right| \exp i \Delta^{\mathrm{P}}{ }_{(\mathrm{r}-\mathrm{i})} \\
& \hat{\gamma}^{\mathrm{S}}=\hat{E}^{\mathrm{S}(\mathrm{r})} / \hat{E}^{\mathrm{S}(\mathrm{i})}=\left|\gamma^{\mathrm{S}}\right| \exp i \Delta^{\mathrm{S}}{ }_{(\mathrm{r}-\mathrm{i})} .
\end{aligned}
$$

エリプソメトリーでは, 入射光と反射光との形 状変化つまり偏光だ円率変化, $\rho$, を求める。こ の偏光だ円率変化は, 式の上では, $\mathrm{P}$ 偏光と $\mathrm{S}$ 偏 光の反射係数の比で与えられる。

$$
\hat{\rho}=\hat{\gamma}^{\mathrm{P}} / \hat{\gamma}^{\mathrm{S}}=\tan \psi \exp i \Delta
$$

ここでは, $\tan \Psi$ なら゙に $\Delta$ はエリプソメトリー の測定量となり, 各々, 相対反射強度ならびに相 対振幅比と呼ばれる。

$$
\begin{gathered}
\tan \psi=\left|\gamma^{\mathrm{P}}\right| /\left|\gamma^{\mathrm{S}}\right| \\
\Delta=\Delta_{(\mathrm{r}-\mathrm{i})}^{\mathrm{P}}-\Delta_{(\mathrm{r}-\mathrm{i})}^{\mathrm{S}} \cdots
\end{gathered}
$$

(2)の式の界面の反射率は, フレネルならびにド ルーデの反射の公式に従い, 界面の両側の相の屈 折率 (正式には複素屈折率, $\hat{n}=n-i k$ ) の関数之 なる。例えば, 気体相 (屈折率, $\hat{n}_{1}=n_{1}$, 通常 透明なので, $k_{1}=0$ ) と固体相 (屈折率, $\hat{n}_{3}$ ) の 界面の反射率は，Pならびに S成分について以下 のフレネルの公式で決まる。

$$
\begin{aligned}
\hat{\gamma}_{13}^{\mathrm{p}} & =\frac{\hat{n}_{3} \cos \phi_{1}-n_{1} \cos \hat{\phi}_{3}}{\hat{n}_{3} \cos \phi_{1}+n_{1} \cos \hat{\phi}_{3}} . \\
\hat{\gamma}_{13}^{\mathrm{S}} & =\frac{\hat{n}_{1} \cos \phi_{1}-n_{3} \cos \hat{\phi}_{3}}{\hat{n}_{1} \cos \phi_{1}+n_{3} \cos \hat{\phi}_{3}} .
\end{aligned}
$$

ここで, $\Phi_{1}$ は入射角, $\hat{\Phi}_{3}$ はスネルの届折の法 則で与えられる複素屈折率である。

$$
\mathrm{n}_{1} \sin \phi_{1}=\hat{\mathrm{n}}_{3} \sin \phi_{3}
$$

両相間に新たに薄膜相（相 2 ）が生成した場合に は，皮膜内でのくり返し反射干渉を考慮に入れた ドルーデの式となる。

$$
\hat{\gamma}_{123}{ }^{\mathrm{P}(\mathrm{S})}=\frac{\hat{\gamma}_{12}{ }^{\mathrm{P}(\mathrm{S})}+\hat{\gamma}_{23}{ }^{\mathrm{P}(\mathrm{S})} \exp (-i \hat{D})}{1+\hat{\gamma}_{12}{ }^{\mathrm{P}(\mathrm{S})} \hat{\gamma}_{23}{ }^{\mathrm{P}(\mathrm{S})} \exp (-i \hat{D})} \cdots(8)
$$

ここで, $\hat{\gamma}_{12}{ }^{\mathrm{p}(\mathrm{s})} \hat{\gamma}_{23}{ }^{\mathrm{p}(\mathrm{s})}$ は, それぞれP偏光成分 （S 偏光成分）に対する相 1 -相 2 界面でのフレ ネル反射係数, 相 2 一相 3 でのフレネル反射係数 である。Dは皮膜厚さ $d$ と波長 $\lambda$ ，を含む項であり， 多重反射による位相の遅れに対応している。

$$
\hat{D}=4 \pi \hat{n}_{2}\left(\cos \hat{\phi}_{2}\right) d / \lambda
$$

それ故, (3)式で示された測定量, $\Psi$ と $\Delta$ は, (5) 〜 (9)式を計算器により解かれた理論値と比較しな 
がら解析される。

特徴として, 測定值が常に $\mathrm{P}$ 偏光と $\mathrm{S}$ 偏光との 相対值であるので, 光源や光量検出の電気系の時 間変動をあまり厳密に考えなくて良いこと, 位相 差を問題にしているので, 膜厚感度が高いことで ある。一方, 定量性を常に問題としているので, 光学素子の精度あるいは光学素子の取り付け調整 法の善し悪しが測定結果に大きく反映する。

\section{3. 測定装置}

エリプソメトリーの装置（エリプソメーター, 偏光反射解析装置) としては, 消光型と光電測光 型に大別される。

消光型エリプソメーターの最む基本的な配置の 模式図を図 4 に示す。光源としては, 水銀ランプ, タングステンランプなどからの光を光学フィルター とコリメーターとで調整した単色平行光や各種の 単波長レーザー光が用いられている。図 2 での偏 光素子の配列は, 偏光子 $(\mathrm{P}), \lambda / 4$ 位相補正子 (C), 反射試料 (S), 検光子 (A)になっている (PCSA配置) が，CがSの後に置かれたPSCA配 置のものも良く使われている。標準的な消光点法 では，Cの進相軸を，入射面から測った方位角を （ $\pi / 4$ ) radianに固定し，PとAの方位角を調整 して，透過する光の量が最小になるようにする。 光量最小点 (消光点) でのP, Aの方位角, $P, A$ は, (3)式内の $\Psi$ と $\Delta$ と次の関係にある。

$$
\psi=A, \Delta=2 P+(1 / 2) \pi
$$

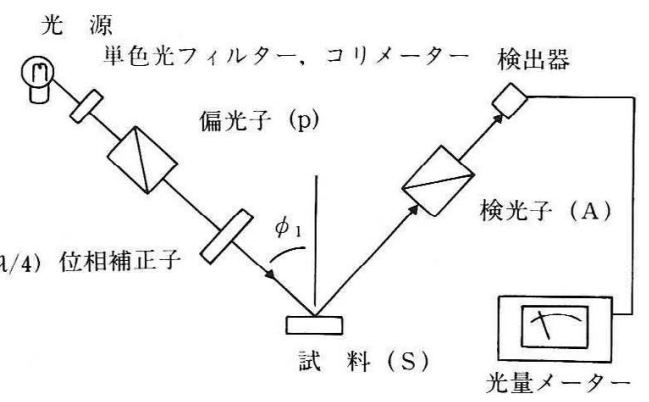

図4 消光型エリプソメーターの光学素子の基本配置 光源のランプ, 単色光フィルター, コリメーターの代わりに単 波長レーザーが用いられることが多くなってきた。また，検出 器としては, 光電子倍增管あるいは半導体検出器 (フォトセル) が用いられる。
光電測光型エリプソメーターの代表として, 回 転検光子型が一般的に使われている。図 4 の装置 で $\mathrm{P}, \mathrm{C}$ の方位角を一定にし，Sからの反射偏光 の形状を，Aの方位角と透過光の強度との関係か ら決める。例えば, 光路からCが取り除かれた最 屯簡単なPSA 配置では, 次の光強度と $\mathrm{P}, \mathrm{A}$ の方 位角の関係から $\Psi$ と $\Delta$ が求められる。

$$
\begin{aligned}
R & =R^{\circ}\left[\left(\tan ^{2} \psi \cos ^{2} P+\sin ^{2} P\right)\right. \\
& +\left(\tan ^{2} \psi \cos ^{2} P-\sin ^{2} P\right) \cos ^{2} A \\
& \left.+\tan \psi \cos \Delta \sin ^{2} P \sin ^{2} A\right] \cdots \cdots(10)
\end{aligned}
$$

(10)式から, 回転検光子を用いて， $\Psi$ と $\Delta$ を実際 に決めるときには, 計算器による簡単なフーリエ 変換が使われる。

消光型ならびに光電測光型とあに，自動化され た市販品が提供されている。図 5 に回転検光子法 を用いた自動エリプソメーターの装置の一例の外 観を示す。

\section{4. 測定試料}

エリプソメトリーにおいて重要なことは, 测定 表面が光学的に平滑でなければならないというこ とである。式(5)～(9)までに展開されている理論の 仮定には, 固体表面が光学的に平滑という条件が 入っている。測定対象物は, それ故, 鏡面程度ま では平滑であるべきである。粗面に対する補正式 が 2,3 の研究者により議論されているが, 実際 の面の粗度の定量的光学的な表し方が困難であり, あまりうまくは補正できないようである。固体表

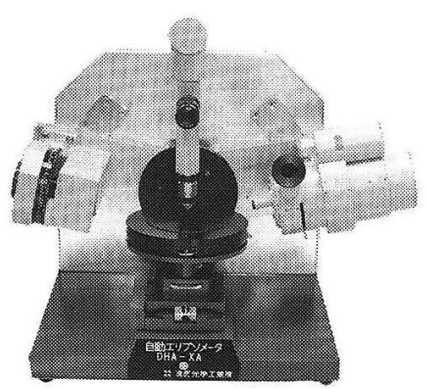

図 5 回転検光子型の自動エリプソメーター (满尻光学工業所 $\mathrm{DHA}-\mathrm{XA}$ 型)

光源はHe-Neレーザーの他, ダイオードレーザ数種の切換の マルチ光源で入射角自動設定方式で各種の被膜測定に有利であ る。 


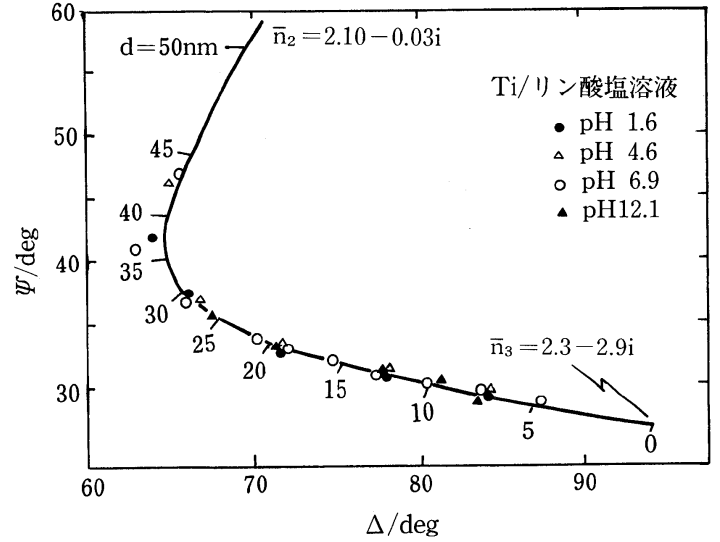

図6 種々のpHのリン酸ナトリウム水溶液中でアノ一 ド酸化生成されたチタンの酸化物皮膜の成長に伴う $\Psi$ $\Delta$ 軌跡

実線は, $n_{3}=2.3-2.9 i$ (下地チタンの屆折率), $n_{2}=2.1-$ $0.03 i$ (皮膜の屈折率) から計算された皮膜厚さをパラメーター とした理論曲線。波長は $546.1 \mathrm{~nm}$, 入射角は 60 degree $(\pi / 3 \mathrm{r}$ adian)。Ohtsukaらの結果による5)。

面の光学的平滑さを除けば, 試料に対する制限は なく, 金属のような非常に光吸収の強いむのから, ガラスのような透明体までの表面の測定が可能と なる。また, 適当な光学空を付属されたセルを用 意すれば, 真空下あるいは溶液中でも測定可能で ある。

\section{5. 測 定 例}

\section{1 金属上の酸化物皮膜}

金属の陽極酸化により，表面に耐食性などの機 能を付与することは多く行われている。図 6 は, チタンの陽極酸化の測定結果である ${ }^{5)}$ 。実験は光 学空付き電気化学セルを用い, 各種のpHのリン 酸ナトリウム水溶液で, 電位を所定の一定值に 1 時間保持した後, 測定された。図の結果は電位 1 $\mathrm{V} \sim 11 \mathrm{~V}$ (vs. 水素電極照合) の範囲のあのであ る。また, 図内の実線は, 式(5)〜 (9)から, 下地チ夕 ン金属の屈折率 $n_{3}=2.3-2.9 i$, 酸化物皮膜の 屈折率を $n_{2}=2.1-0.03 i$ として計算された皮膜 成長に伴う $\Psi-\Delta$ の関係である。これらの屈折率 は, 測定点に合うように, 計算から選び出したも のである。このような理論 $\Psi-\Delta$ 曲線と実験值 の比較から実際の皮膜厚を $0.1 \mathrm{~nm}$ オーダーの精

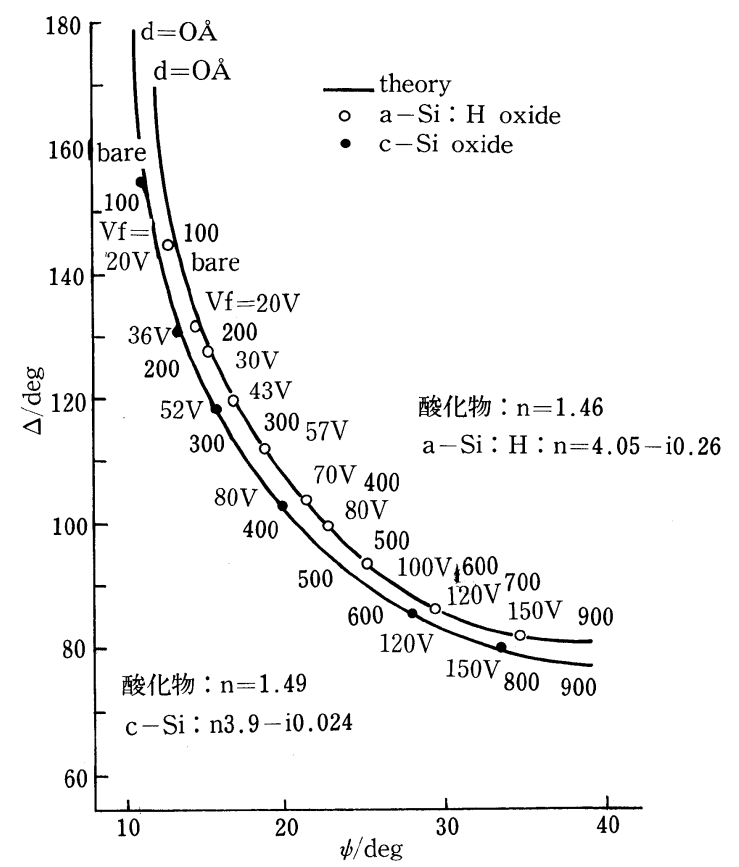

図 7 単結晶シリコン ( $\mathrm{c}-\mathrm{Si})$ ならびにアモルファス シリコン（a-Si）上に生成したアノード酸化物皮膜の 成長に伴う $\Psi-\Delta$ 軌道

図の実線は図中の屈折率から引かれた理論線。波長は632.8nm, 入射角は70degree。Yamamotoらの結果による。 ${ }^{6)}$

度で決定しうる。

図 6 の結果は水溶液内での金属上の酸化物皮膜 形成であるが, 気相との反応による皮膜形成に関 しても多くの適用例がある。

\section{2 半導体上での酸化物皮膜}

半導体をデバイスとして利用する時には, 種々 の手法により酸化物あるいは窒化物の皮膜を絶縁 膜として形成される。このような絶縁膜の厚さ検 出, 制御にエリプソメトリーは応用されている。 また, 半導体上のレジストの膜厚制御にも応用さ ている。

図7 は, 単結晶シリコンならびにアモルファス シリコン上に, 硝酸カリウムが添加されたエチレ ングリコール溶液中でアノード酸化されたシリコ ン酸化物の皮膜成長に伴う $\Psi-\Delta$ 軌跡之, その理 論線を示してある ${ }^{6)}$ 。図から，単結晶シリコンと アモルファスシリコンの屈折率が異なること,な らびに上に生成する皮膜 (主に $\mathrm{SiO}_{2}$ )の屈折率も 異なることが分かる。図 6 の測定から, 皮膜の成 長は $0.53 \mathrm{~nm} / \mathrm{V}$ の割で起こることが結論されて 


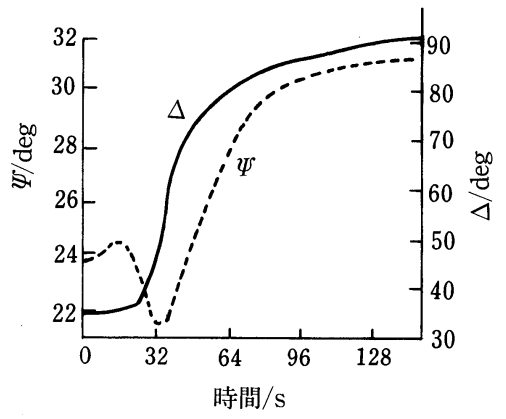

図 8 アモルファスカーボン上への $\mathrm{Ni}$ の電析過程時の $\Psi$ と $\Delta$ の時間変化

電解液組成は, $0.1 \mathrm{M} \mathrm{NiSO}_{4}, 0.6 \mathrm{M} \mathrm{NaCl}$, および $0.58 \mathrm{MH}$ ${ }_{3} \mathrm{BO}_{4}$ からなる。入射角は70degeree, 波長は $546.1 \mathrm{~nm}$ である。 Abyaneh らの結果による ${ }^{7}$ 。

いる。

シリコン以外の半導体上の絶縁膜形成の研究結 果も報告されている。

\section{3 電析皮膜の検出}

めっき層の膜厚をエリプソメトリーで求める実 験も報告されている。金属めっき層の光吸収が大 きいため, $0.1 \mu \mathrm{m}$ 以上になると膜厚感度はなく なると予想さる。図 8 は, アモルファスカーボン 電極にニッケルが電析していく過程をエリプソメ トリーで追跡した結果である ${ }^{7}$ )。表面の形状 (粗 度) が電析とともに変化していくので, 図 8 の結 果から, 定量的に皮膜厚さを計算できないが, 定 性的には電析皮膜の成長過程をモニターするのに 使うことができるであろう。

\section{6. 最近の話題}

エリプソメトリーは, 膜厚測定器としての装置 としては充分完成したものになっているであろう。

エリプソメトリーをさらに表面解析器として使 用するための工夫が続いている。エリプソメトリー に分光測定機能を付けることにより, 薄膜の分光 的なキャラクタリゼーシションの試み，あるいは， 顕微測光之結び付けた局所膜厚測定の試みなどで ある。

図 9 は顕微エリプソメトリーの測定結果の一例 であり, Tin Free Steel (TFS)のクロム/クロム 水和酸化物 2 重層の皮膜厚さの場所による分布を 測定した例である ${ }^{8)}$ 。 1 点の測定点は, $30 \mu \mathrm{m} \times$
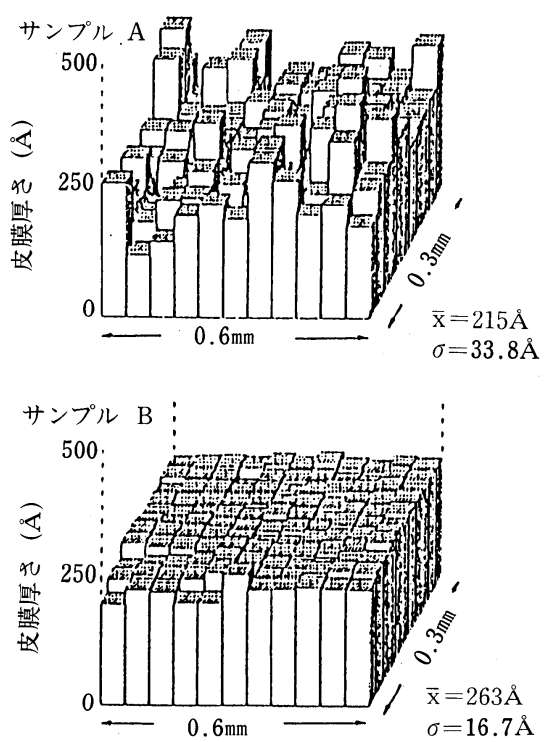

図 9 顕微エリプソメーターによるTFS のクロム/ク 口ム水和酸化物皮膜の膜厚分布

1 点の測定点は $30 \mu \mathrm{m} \times 60 \mu \mathrm{m}$ に対応している。和平均厚さ, $\sigma$ は標準偏差を示している。山本らの結果による ${ }^{8)}$ 。

$60 \mu \mathrm{m}$ の面積に対応している。試料の処理により, 膜厚分布に差があり, その分布状態がTFS の耐食 性に影響することが見い出されている。

\section{7. おわりに}

エリプソメトリーの原理, その応用例の簡単な 紹介を行った。エリプソメトリーは非常に定量性 の高い手法であるが，一方非常に厳密な仮定の上 でその解析がなされている。それ故, 皮膜の屈折 率の決め方など解析を行う上で必要なパラメーター を求めていく時に, 計算が煩雑になっていく。 エリプソメトリーの定量性の面を弱め, 例えば表 面のモニターリング手法と考えれば, より多くの 系に簡単に応用できる。図 7 の電析の結果などは, 今までのエリプソメトリーの理論から定量的な答 えを出すことは非常に困難と思われるが, 電析の モニターリングと考えると多くの現場で使用しう るであろう。

最後に, 本稿執筆にあたり, 貴重なご助言をい ただいた北海道大学大塚俊明先生に心より感謝い たします。

(1988-11-30 受理) 


\section{文献}

1）工藤清勝, 佐藤教男; 北海道大学工学部研究報告, 41, 141 (1968)

2) F. L.McCrackin ; National Bureau of Standards, Tech. Note., 479, US Dept. of Commerce (1969)

3) R. M. A. Azzam and N. M. Bashara ; "Ellip sometry and Polarized Light ", North-Holland Publ. Co., Amsterdam (1977)

4）横田英嗣; 光学的測定ハンドブック, 田幸敏治他 編集，p．87，256，373(朝倉書店，1981)
5) T. Ohtsuka, M. Masuda and N. Sato ; $J$. Electrochem. Soc., 132, 787 (1985)

6) H. Yamamoto, S. Arimoto, H. Hasegawa and H. Ohno ; Electronics Letters, 19, 6 (1983) 南条淳二, 山本秀也, 沢田孝幸, 長谷川英樹; 電 気化学, 51，440 (1983)

7) M. Y. Abyaneh, W. Visscher and E. Bar end-recht ; Electrochem. Acta, 28, 385 (1983) 8）山本正弘, 浅井恒敏, 前田重義; 金属表面技術, 39, 452 (1988) 